\title{
Emotional and Behavioral Problems in Children Living With Addicted Family Members: Prevention Challenges in an Underprivileged Suburban Community ${ }^{1}$
}

\author{
Thaís dos Reis Vilela ${ }^{2}$ \\ Rebeca de Souza e Silva \\ Universidade Federal de São Paulo, \\ São Paulo-SP, Brazil \\ Universidade Federal de São Paulo, \\ São Paulo-SP, Brazil \\ Camila Garcia de Grandi \\ Universidade Federal de São Paulo, \\ São Paulo-SP, Brazil \\ Marina Monzani da Rocha \\ Neliana Buzi Figlie \\ Universidade Presbiteriana Mackenzie, \\ São Paulo-SP, Brazil \\ Universidade Federal de São Paulo, \\ São Paulo-SP, Brazil

\begin{abstract}
Children living with substance abusers are more likely to experience negative outcomes. Our goal was to compare caregivers' reports on the Child Behavior Checklist (CBCL) and a socioeconomic and risk form of psychological aspects of children exposed to substance abuse assisted versus not assisted by a preventive intervention program in an underprivileged community. This observational intervention study was conducted with 66 caregivers of children who attended the program and 35 caregivers of children from the same community who did not attend. Ages ranged between six and 11 years old. Chi-square and logistic regression tests indicate that children exposed to substance abusers have more mental health problems than the general population and those who did not participate in the preventive intervention program presented worse outcomes, with higher rates of behavioral/emotional problems and exposure to risk situations. Results suggest that preventive actions might be helpful to promote the mental health of children at risk, validating the need for public policies and services.
\end{abstract}

Keywords: substance-related disorders, child behavior checklist, mental health, risk factors, drug abuse prevention

\section{Problemas Emocionais e Comportamentais de Crianças que Convivem com Familiares Dependentes Químicos: Desafios de Prevenção em uma Comunidade Suburbana Desfavorecida}

\begin{abstract}
Resumo: Crianças que convivem com usuários de substâncias psicoativas são mais propensas a apresentar problemas. O objetivo deste estudo foi comparar, a partir dos relatos dos cuidadores no Child Behavior Checklist (CBCL) e numa ficha de dados sociodemográficos e de fatores de risco, aspectos psicológicos de crianças expostas ao abuso de substâncias assistidas e não assistidas por um programa de intervenção preventiva, em uma comunidade desfavorecida. O estudo observacional de intervenção foi conduzido com 66 cuidadores de crianças que passaram pela intervenção e 35 da mesma comunidade que não foram atendidas. A faixa etária era de seis a 11 anos. Os testes qui-quadrado e regressão logística indicaram que as crianças expostas ao abuso de substâncias apresentaram mais problemas de saúde mental do que a população geral e que aquelas que não participaram do programa preventivo apresentaram desfechos piores, com escores mais elevados de problemas emocionais/comportamentais e maior exposição a situações de risco. Sugere-se que ações preventivas podem contribuir para a promoção de saúde mental em crianças em situação de risco, validando a necessidade de políticas e serviços públicos.
\end{abstract}

Palavras-chave: transtornos relacionados ao uso de substâncias, lista de verificação comportamental para crianças, saúde mental, fatores de risco, prevenção do abuso de drogas

\section{Problemas Emocionales y de Comportamiento en Niños que Viven con Familiares Adictos: Desafios de Prevención en una Comunidad Suburbana Desfavorecida}

\begin{abstract}
Resumen: Los niños que viven con consumidores de drogas son más propensos a tener problemas. Nuestro objetivo fue comparar, a partir de los informes de los cuidadores en el Child Behavior Checklist (CBCL) y en una hoja de datos sociodemográficos y de factores de riesgo, aspectos psicológicos de niños expuestos al abuso de sustancias, con y sin la asistencia de un programa de intervención preventiva en una comunidad desfavorecida. Este estudio de intervención observacional fue realizado con 66 cuidadores de niños que pasaron por la intervención y 35 de la misma comunidad que no fueron atendidos. Las idades oscilaran entre seis y 11 años. Las pruebas de chi-cuadrado y regresión logística indicaron que los niños expuestos al abuso de sustancias tenían más problemas de salud mental en comparación con la población general y que aquellos que no participan del programa de prevención tuvieron peores resultados, con una puntuación más alta de problemas emocionales y de conducta y una mayor exposición al riesgo. Se sugiere que las acciones preventivas puedan contribuir a la promoción de la salud mental en los niños en situación de riesgo y se valida la necesidad de políticas y servicios públicos.
\end{abstract}

Palabras clave: trastornos relacionados con sustancias, lista de verificación del comportamiento infantil, salud mental, factores de riesgo, prevención en el abuso de drogas

\footnotetext{
${ }^{1}$ Article derived from the third author master's thesis under the supervision of the fifth author, defended in 2012, in the Graduate Program in Psychiatry and Medical Psychology at the Universidade Federal de São Paulo.

Support: Scholarship granted by the Coordination for the Improvement of Higher Education Personnel (CAPES) to the third author.
}

${ }^{2}$ Correspondence address:

Thaís dos Reis Vilela. Av. Corifeu de Azevedo Marques, 3202, apt 174-D, Jardim das Indústrias. CEP 12241-040. São José dos Campos-SP, Brazil. E-mail: thaisvilela1@gmail.com 
The impact of alcohol abuse and substance dependence in children exposed to them has been widely researched and reported in international literature. However, in Brazil, this population has only recently started to receive attention, which makes it impossible to estimate how many children live with this problem.

International prevalence studies of child mental health found rates ranging from $9 \%$ to $20 \%$ of psychiatric disorders in developed countries (Fleitlich \& Goodman, 2002). Although there is a paucity of epidemiological research in developing countries, preliminary studies indicate rates on the same range. Specifically in Brazil, different rates of mental health problems have been reported. Feitosa, Ricou, Rego, and Nunes (2011) found a 10\% rate when studying children from middle class urban and underprivileged rural areas. Paula, Duarte, and Bordin (2007) identified a $24.6 \%$ rate of prevalence of mental health problems on the outskirts of Sao Paulo city. Vitolo, Fleitlich-Bilyk, Goodman, and Bordin (2005) indicated a $35.2 \%$ prevalence of clinical cases in a school-based sample from Taubaté-SP, while Assis, Avanci, Pesce, Oliveira, and Furtado (2007) found the occurrence of $3.5 \%$ for internalizing problems, $4 \%$ for externalizing and $1.3 \%$ for attention problems in a school-based sample from São Gonçalo-RJ. The discrepant rates found on these studies suggests that we still do not understand the global impact of child mental health in Brazil.

On the other hand, associations between behavior disorders and family environment variables have been found consistently. The amount of negative family events is pointed out as particularly harmful to children's development, being a factor that leads to behavior problems, altogether with exposure to poverty, maternal psychiatric illness and domestic violence (Fatori, Bordin, Curto, \& Paula, 2013). Besides, the association between domestic violence and community problems with internalizing and externalizing problems is observed in the literature. This indicates a strong relation between community violence and mental functioning of the child, since in this context the sense of security can be jeopardized, yielding negative effect on his/ her development (Huculak, McLennan, \& Bordin, 2011; Murray, Anselmi, Gallo, Fleitlich, \& Bordin, 2013).

Parental addiction is associated with several negative outcomes on the child development. Investigations from the last three decades have shown that having a substance abuser parent increases from two to nine times the risk of developing substance misuse later, despite the good results of adaptive behavior of many of these children (Beard et al., 2010; Kumpfer \& Johnson, 2007). Children of substance abusers were found to be more likely to consume and face substance use related problems (Buu et al., 2012). Moreover, these individuals tends to start the consumption of alcohol and drugs earlier, when compared to children of non-addicts and, in early adolescence, have significantly higher odds of drinking alcohol, using illicit drugs, drinking heavier, and presenting addiction symptoms (Adkison et al., 2013).

Besides the risk for addictive behaviors, children of substance abusers are also at higher risk of developing emotional, behavior, academics, criminal and other social problems (Barnow, Ulrich, Grabe, Freyberger, \& Spitzer, 2007). Some authors report an increasing frequency of delinquency, social inadequacy and somatic problems (Serec et al., 2012; Temple, Shorey, Fite, Stuart, \& Le, 2013), while others also report that these children show high levels of anxiety, depression, and show widespread stress, depressive humor and attention deficit-hyperactivity disorder (Chen et al., 2013; Klostermann et al., 2011; Mackrill \& Hesse, 2012).

It is well recognized by health professionals that children from substance-affected families are in a vulnerable condition for developing substance related problems or other mental health issues. On the other hand, few preventive programs targeted at this specific group have been scientifically studied. Bröning et al. (2012) conducted a systematic review of the literature on this subject and found nine programs - four school based intervention, one community based intervention and four family-based interventions - with preliminary evidence of effectiveness. All programs were conducted in the United States, except for one adaptation of an American program conducted in Spain and in Canada. In Brazil, reports of programs designed specifically for children of substance abusing parents were not found.

In 2001, a pioneer selective prevention program was implemented in the outskirts of São Paulo city focused on children between zero and 17 years-old, living with addicted family members (CUIDA - Utility Intervention and Support Center for Children of Substance Abusers). It main concerns were: to promote protection of emotional and behavioral problems and coping skills for stressful situations; to prevent psychoactive substances consumption and exposition to drugs trafficking; to ensure educational conditions, social and recreational integration; to strengthen the social networking between the families; and to provide damage reduction associated to the consumption of substances by the addicted family members (Figlie, Milagres, \& Crowe, 2009).

Figlie, Fontes, Moraes, and Payá (2004) conducted the first study describing CUIDA and characterizing children of substance abusers in Brazil. The authors reported that children assisted by the program showed behavioral characteristics similar to those found in the international literature, with predominance of feelings of insecurity and inadequacy associated with depression, apathy and repression. They also noted the presence of fights, difficulties in family relationships and aggressive behavior, in addition to lowered self-esteem, high rates of affection privation, use of defenses such as problems denial, impoverishment in the ability to solve problems, isolation and early maturity. This first study not only described the children and adolescents treated at CUIDA but also emphasized the need of a preventive intervention program for this population.

Apart for that, this is one of the first studies conducted in Brazil aimed to assess the social and psychological aspects of children living with addiction in their families. Our 
purpose was to compare caregivers reports of psychological aspects of children exposed to substance abuse assisted versus not assisted by a preventive intervention program in an underprivileged community of São Paulo, Brazil.

\section{Method}

\section{Participants}

This is an observational intervention study that included 101 caregivers of six to 11 years old children exposed to substance abuse in their families. Inclusion criteria were: the child had to live with at least one addicted family member; to reside in Jardim Ângela neighborhood; to be a volunteer. They were divided in two groups, 66 caregivers of children ( $M=9.41$ years, $S D=1.51)$ who attend CUIDA for at least one year (Intervention Group) and 35 caregivers of children ( $M=8.69$ years, $S D=1.73$ ) from the same neighborhood who attend municipals Centers for Children and Adolescents (CCA), but not CUIDA or any other preventive intervention center for substance abuse (Control Group).

CUIDA offered mental health assistance and other activities, such as educational, recreational, musical, sports and computational. Psychologists, social workers and a pediatrician carried out the assistance individually or in groups. All activities took place outside the regular school time-period and all participants received nourishment. The Control Group children attended CCA, which main goal is to be a place where children be together and interact in a health way through recreational, cultural and sportive activities, not to give any substance abuse preventive program.

The present study was conducted in two services offered by a non-governmental organization in the neighborhood of Jardim Ângela, on the outskirts of São Paulo. This area comprised the highest alcohol outlet density reported in the medical literature. A study revealed the proportion of approximately one alcohol selling point per twelve properties. In the late 90 s, the United Nations ranked this area as the most violent neighborhood in the world (Laranjeira \& Hinkly, 2002).

\section{Instruments}

In order to assess child's exposure to addiction, it was used the familiar CAGE questionnaire (acronym of its four questions: Cut down on drinking; Annoyed by criticizing about drinking; Guilty about drinking; had an Eye-opener first thing in the morning), a screening tool, which consists of four items that aim to detect family problems related to alcohol consumption. This instrument was found to be a consistent and effective measure of alcohol misuse in families. Originally aimed to measure alcohol consumption, it was changed to include other drugs (marijuana, cocaine and crack). Studies demonstrate internal consistency of $84 \%$ to $89 \%$ (Frank, Graham, Zyzanski, \& White, 1992). The version used was based on the validation in which was found $88 \%$ of sensitivity range for the CAGE (Masur
\& Monteiro, 1983). The used cut-offs correspond to an affirmative answer.

The Child Behavior Checklist Ages 6 to 18 (CBCL/618) was used to assess emotional and behavioral problems. The CBCL is a questionnaire developed in the United States, and validated for different cultures, in which parents evaluate their child behaviors (Achenbach \& Rescorla, 2001). Two areas are assessed: Competences and Behavioral/Emotional Problems, being this last one divided in three large scales: Total Problems, Internalizing, and Externalizing. Raw items scores are converted in T-scores, which are classified as normal, borderline or clinical in comparison with a normative sample of children not referred for mental health services.

In Brazil, its psychometric proprieties has being stablished by a few studies. The first indicated high sensitivity of the instrument in comparison with psychiatric assessment: $87 \%$ of the clinical cases were identified (Bordin, Mari, \& Caiero, 1995). This was confirmed in comparison with results found using a semi-structured psychiatric interview (K-SADS-PL): $82.4 \%$ of children with psychiatric disorders achieved clinical scores on the CBCL (Brasil \& Bordin, 2010). Using the latest version of the CBCL, Rocha et al. (2013) reported the validity of its factorial structure (RMSEA $=.023$ ), the discriminative capacity of the instrument $(p<.001)$, and suggested more appropriate normative standards for assessing our population. A review article giving detailed information on the development of these forms in the United States and Brazil was recently published (Bordin et al., 2013).

Considering Rocha et al. (2013) findings regarding norms and cutoff points for the clinical range, group 3 norms, indicated by Achenbach and Rescorla (2007) multicultural study, were used. Besides, borderline and clinical range scores were grouped following Achenbach and Rescorla (2001) instructions to avoid false negatives.

Moreover, questions aimed at sociodemographic description of the sample concerning gender, age, color, religion, educational level, socioeconomic status, family substance abuse, and stress situations experienced were asked.

\section{Procedure}

Data collection. The study was carried out from August 2010 to December 2011. According to CUIDA's records, 791 children and adolescents attended the service and 174 were aged six to 11 when data collection was conducted. Researchers tried to locate all Intervention Group potential participants by either phone or home visits. A total of 66 (38\%) caregivers accepted to participate in the research and completed all forms, $38(22 \%)$ refused to participate, $37(21 \%)$ were not located, nine $(5 \%)$ had moved to another city and two (1\%) reported their children had never attended CUIDA. Besides, 22 (13\%) of the children were institutionalized and were not living with their originated family.

To compose the Control Group children from the same region were allocated from social work services, community-based recreation activities and leisure services 
specially designed for children. For both groups, data were collected by a psychologist who conducted a 60-minute face-to-face interview with the informant at the preventive service location, as well as at the social work services designed for the child, or during home visits. All forms were filled out during this interview.

Data analysis. Data were analyzed using the Statistical Package for the Social Sciences (SPSS 15.0) and involved descriptive and inferential statistics. Initially, descriptive statistics regarding sociodemographic characteristics and CBCL scores of both groups were performed. Chisquare tests were used to compare the distribution of all variables on both groups. Then a logistic regression model was adjusted to understand the relationship between both groups, their characteristics and CBCL scores. All sociodemographic variables were included in the model as independent variables, in addition to the Internalizing, Externalizing, Total Problems and Total Competence Scales, whereas group (Intervention vs. Control) were included as dependent variables. Analysis was controlled for gender, age, Brazil Economic Classification Criteria, type of drug (alcohol or illicit) and substance abuser family member. The covariates above were retained regardless of significance and variables not significant at $5 \%(p<.05)$ were eliminated by the stepwise selection method. Odds ratio were used to assess the risk of not attending CUIDA. Values bellow 1 were considered protective factors, while values above 1 were considered risk factors.

\section{Ethical Considerations}

The study was approved by the Ethics Committee of the Universidade Federal de São Paulo (EPMedicina/ UNIFESP - CEP n.1843/09) and by the Ethics Committee in Research of the Municipal Health Department of São
Paulo (CAAE n. 05.174/11) and contemplated all ethical guidelines in Resolution No. 196/96 of the National Health Council of the Ministry of Health.

All protocols contained an informed consent form properly signed ensuring the anonymity of the participant and confidentiality of information. All of the participants were informed of the nature, content, and propose of the interviews and requested to sign an Informed Consent for Participation.

\section{Results}

Descriptive statistics with sociodemographic data and the family stressful situations reported by the participants of the two groups are presented in Table 1. Groups were equivalent in most of the variables. Chi-square test indicated significant differences regarding age, religion, education and stress in the following situations: suicide, attempted suicide and family member death, all occurring in the year preceding the interview.

The age difference between the groups is due to the different configuration: Intervention Group has more children between 9-11 years old than the Control Group $(77.3 \%$ vs. $57.1 \%)$. Intervention Group has also the highest number of people who have a religion $(91.8 \%$ vs. $62.9 \%$ in Control Group).

Regarding education, the significance also takes place due to the age difference, since the percentage of grade repetitions is minimal. Since there is no significance in the variable number of repetitions and all children in the sample are in school, there is no significant school delay in either group.

In relation to situations of stress experienced by the child, there was significant difference in the items suicide, suicide attempt and death of family member. In all three cases, there are a greater number of occurrences in the Control Group.

Table 1

Distribution of Sociodemographic Characteristics and Stressful Situations $(N=101)$

\begin{tabular}{|c|c|c|c|c|c|c|c|}
\hline & \multicolumn{2}{|c|}{$\begin{array}{l}\text { Intervention Group } \\
\qquad(n=66)\end{array}$} & \multicolumn{2}{|c|}{$\begin{array}{l}\text { Control Group } \\
\quad(n=35)\end{array}$} & \multicolumn{2}{|c|}{$\begin{array}{c}\text { Total } \\
(n=101)\end{array}$} & \multirow[t]{2}{*}{$p$} \\
\hline & $N$ & $\%$ & $n$ & $\%$ & $n$ & $\%$ & \\
\hline Gender & & & & & & & .929 \\
\hline Female & 27 & 40.9 & 14 & 40.0 & 41 & 40.6 & \\
\hline Male & 39 & 59.1 & 21 & 60.0 & 60 & 59.4 & \\
\hline Age* & & & & & & & .035 \\
\hline 6 to 8 years old & 15 & 22.7 & 15 & 42.9 & 30 & 29.7 & \\
\hline 9 to 11 years old & 51 & 77.3 & 20 & 57.1 & 71 & 70.3 & \\
\hline Color & & & & & & & .072 \\
\hline White & 29 & 43.9 & 09 & 25.7 & 38 & 37.6 & \\
\hline Non-white & 37 & 56.1 & 26 & 74.3 & 63 & 62.4 & \\
\hline
\end{tabular}




\begin{tabular}{|c|c|c|c|c|c|c|c|}
\hline & \multicolumn{2}{|c|}{$\begin{array}{l}\text { Intervention Group } \\
\qquad(n=66)\end{array}$} & \multicolumn{2}{|c|}{$\begin{array}{l}\text { Control Group } \\
\quad(n=35)\end{array}$} & \multicolumn{2}{|c|}{$\begin{array}{c}\text { Total } \\
(n=101)\end{array}$} & \multirow[t]{2}{*}{$p$} \\
\hline & $N$ & $\%$ & $n$ & $\%$ & $n$ & $\%$ & \\
\hline Religion* & & & & & & & .000 \\
\hline Yes & 56 & 91.8 & 22 & 62.9 & 78 & 81.3 & \\
\hline No & 05 & 8.2 & 13 & 37.1 & 18 & 18.8 & \\
\hline Children Educational level* & & & & & & & .007 \\
\hline Up to E.F.1 Completed (equivalent to 3rd grade) & 47 & 71.2 & 33 & 94.3 & 80 & 79.2 & \\
\hline Up to E.F.2 Uncompleted (equivalent to 5 th grade) & 19 & 28.8 & 02 & 5.7 & 21 & 20.8 & \\
\hline School Repetitions & & & & & & & .961 \\
\hline None & 64 & 97.0 & 34 & 97.1 & 98 & 97.0 & \\
\hline One & 02 & 3.0 & 01 & 2.9 & 3 & 3.0 & \\
\hline Brazil Economic Classification Criteria & & & & & & & .692 \\
\hline Class B & 01 & 1.5 & 01 & 2.9 & 02 & 2.0 & \\
\hline Class $\mathrm{C}$ & 46 & 70.8 & 22 & 62.9 & 68 & 68.0 & \\
\hline Class D & 18 & 27.7 & 12 & 34.3 & 30 & 30.0 & \\
\hline Parents' marital status: Married? & & & & & & & .579 \\
\hline Yes (married or living together) & 34 & 51.5 & 16 & 45.7 & 50 & 49.5 & \\
\hline No (single, divorced, separated) & 32 & 48.5 & 19 & 54.3 & 51 & 50.5 & \\
\hline Number of substance abusers who coexists & & & & & & & .522 \\
\hline One substance abuser & 47 & 71.2 & 27 & 77.1 & 74 & 73.3 & \\
\hline More than one substance abuser & 19 & 28.8 & 8 & 22.9 & 27 & 26.7 & \\
\hline Substance Abuser Member & & & & & & & .068 \\
\hline First-degree relatives & 57 & 86.4 & 25 & 71.4 & 82 & 81.2 & \\
\hline Second-degree relatives & 09 & 13.6 & 10 & 28.6 & 19 & 18.8 & \\
\hline Type of drug consumed & & & & & & & .159 \\
\hline Alcohol & 38 & 57.6 & 15 & 42.9 & 53 & 52.5 & \\
\hline Illicit drug & 28 & 42.4 & 20 & 57.1 & 48 & 47.5 & \\
\hline \multicolumn{8}{|l|}{ Stressful situations } \\
\hline Psychiatric hospitalization & 07 & 11.5 & 09 & 25.7 & 16 & 16.7 & .072 \\
\hline Family severe disease & 19 & 30.6 & 13 & 37.1 & 32 & 33.0 & .513 \\
\hline Suicide* & 01 & 1.6 & 08 & 22.9 & 09 & 9.3 & .001 \\
\hline Attempted suicide* & 04 & 6.5 & 11 & 31.4 & 15 & 15.5 & .001 \\
\hline Police problems & 10 & 16.1 & 09 & 25.7 & 19 & 19.6 & .253 \\
\hline Death of a family member* & 12 & 19.422 & 15 & 42.9 & 27 & 27.8 & .013 \\
\hline Physical aggression between family & 14 & 6 & 14 & 40.0 & 28 & 28.9 & .069 \\
\hline
\end{tabular}

${ }^{*} p<.05$.

Table 2 shows the frequency of clinical and nonclinical CBCL scores. The percentage of children with scores in the clinical range on Internalizing, Externalizing and Total Problems scales at Control Group is considerably higher in comparison to Intervention Group $(51.4 \%$ vs. $13.6 \%, 60 \%$ vs. $30,3 \%$ and $62.9 \%$ vs. $28.8 \%$, respectively). The Total Competence Scale has not shown significant difference. 
Table 2

Distribution of CBCL Scores in the Groups $(N=101)$

\begin{tabular}{|c|c|c|c|c|c|c|c|}
\hline & \multicolumn{2}{|c|}{$\begin{array}{l}\text { Intervention Group } \\
\qquad(n=66)\end{array}$} & \multicolumn{2}{|c|}{$\begin{array}{l}\text { Control Group } \\
\qquad(n=35)\end{array}$} & \multicolumn{2}{|c|}{$\begin{array}{c}\text { Total } \\
(N=101)\end{array}$} & \multirow[t]{2}{*}{$p$} \\
\hline & $n$ & $\%$ & $n$ & $\%$ & $n$ & $\%$ & \\
\hline Internalizing Scale ${ }^{\mathrm{a} * *}$ & & & & & & & .000 \\
\hline Non-clinical & 57 & 84.4 & 17 & 48.6 & 74 & 73.3 & \\
\hline Clinical$^{\S}$ & 09 & 13.6 & 18 & 51.4 & 27 & 26.7 & \\
\hline Externalizing Scale $\mathrm{e}^{\mathrm{b} * *}$ & & & & & & & .004 \\
\hline Non-clinical & 46 & 69.7 & 14 & 40.0 & 60 & 59.4 & \\
\hline Clinical $^{\S}$ & 20 & 30.3 & 21 & 60.0 & 41 & 40.6 & \\
\hline Total Problems Scale ${ }^{c * *}$ & & & & & & & .001 \\
\hline Non-clinical & 47 & 71.2 & 13 & 37.1 & 60 & 59.4 & \\
\hline Clinical $^{\S}$ & 19 & 28.8 & 22 & 62.9 & 41 & 40.6 & \\
\hline Total Competencies Scale ${ }^{\mathrm{d}}$ & & & & & & & .050 \\
\hline Non-clinical & 44 & 66.7 & 28 & 79.4 & 72 & 71.3 & \\
\hline Clinical $^{\S}$ & 22 & 33.3 & 07 & 20.6 & 29 & 28.7 & \\
\hline
\end{tabular}

${ }^{\$}$ Scores in the clinical range in comparison to Group 3 cutpoints (Achenbach \& Rescorla, 2007). ancludes Anxious/Depressed, Withdrawn/ Depressed, and Somatic Complaints subscales. 'Includes Rule Breaking Behavior and Aggressive Behavior subscales. 'Includes all problems items of the CBCL. 'Includes Activities, Social and School subscales.

$* * p<.01$.

Results achieved in the logistic regression test can be observed in Table 3. Among the significant variables in chisquare test, age $\left(\right.$ Wald $\left.^{2}=8.570 ; p=.003\right)$, religion $\left(\right.$ WaldX $^{2}$ $=8.985 ; p=.003)$ and family stress situation death of family member $\left(\right.$ Wald $\left.X^{2}=7.253 ; p=.007\right)$ remained significant in logistic regression model.
The control variable substance abuser member, who did not appear significant in the chi-square test, has achieved significance in the logistic regression model $\left(\right.$ WaldX ${ }^{2}=$ 5.546; $p=.019$ ). From CBCL Scales a significant difference was observed between the Intervention and Control Group on the Internalizing Scale $\left(\right.$ WaldX $\left.^{2}=8.5971 ; p=.003\right)$.

Table 3

Results of Logistic Regression and Odds Ratio (OR) With the Sociodemographic Variables, Stressful Situations and Scores From CBCL (N = 101)

\begin{tabular}{lcccc}
\hline Variables & WaldX & & OR & $95 \% \mathrm{CI}$ \\
\hline Sex $^{\mathrm{a}}$ & .391 & .532 & .666 & {$[.186,2.382]$} \\
Age $^{\mathrm{ab}}$ & 8.570 & .003 & 7.483 & {$[1.945,28.794]$} \\
Religion $^{\mathrm{b}}$ & 8.985 & .003 & .095 & {$[.021, .443]$} \\
Brazil Economic Classification Criteria $^{\mathrm{a}}$ & .157 & .692 & .780 & {$[1.345,25.516]$} \\
Type of drug (alcohol or illicit) $^{\mathrm{a}}$ & 1.089 & .297 & .538 & {$[.168,1.725]$} \\
Substance Abuser Member $^{\mathrm{ab}}$ & 5.546 & .019 & 5.859 & {$[.228,2.669]$} \\
Stress Situation: Death of a family member $^{\mathrm{b}}$ & 7.253 & .007 & .161 & {$[.043, .608]$} \\
Internalizing Scale $^{\mathrm{b}}$ & 8.971 & .003 & .376 & {$[.198, .713]$} \\
\hline
\end{tabular}

${ }^{\mathrm{a}}$ Control variables. ${ }^{\mathrm{b}}$ Significant variables.

\section{Discussion}

Mental health problems of children exposed to substance abuse assisted versus not assisted by a preventive intervention program in an underprivileged community of São Paulo, Brazil were assessed. Results show that, despite the presence of small sociodemographic differences, since Intervention Group was older and more religious, caregivers of the Control Group reported worst mental health indexes and exposure to risk situation. For instance, children that attended the preventive service achieved, on average, normal scores on three of four CBCL scales analyzed: Internalizing, Externalizing and Total Problems, with a greater emphasis towards the Internalizing Scale, which remained in the model logistic regression with significance $(p=.003, O R=.376)$.

Considering the number of children with clinical scores, Intervention Group also had fewer for all problems scales: $13.6 \%$ vs. $51.4 \%$ for Internalizing, $30.3 \%$ vs. $60 \%$ 
for Externalizing, and $28.8 \%$ vs. $62.9 \%$ for Total Problems. These numbers suggest an association between participating of preventive intervention and caregivers reporting less behavioral problems, which also suggests the importance of psychosocial preventive action involving this population.

The implementation of preventive services aimed at children of substance abusers may be key to care for the population living in a low-income area, especially considering the easy access to alcohol and other drugs (Laranjeira \& Hinkly, 2002) and that it is cheaper to implement preventive than curative actions (Robertson, David, \& Rao, 2003). CUIDA's strategies included all sorts of health care professionals to give the children the possibility of developing higher tolerance while dealing with their reality and improve the problem solving capacity. This kind of program is conform to Trim and Chassin (2008) suggestion that multidisciplinary teams should include Psychologists, Psychiatrists, Occupational Therapists, as well as any other professional that could help improve the patients' mental health.

Although caregivers of children from Intervention Group reported less problems than those from Control Group, both groups have higher rates of behavioral problems than found as epidemiological rate for mental health problems in children from urban and poor areas in Brazil, which is $20 \%$ according to Fleitlich and Goodman (2001). The same happens considering the rate of $24.6 \%$ indicated by Paula et al. (2007). On our sample, $26.7 \%$ of the children scored in the clinical range for Internalizing, $40.6 \%$ for the Externalizing, and $40.6 \%$ for the Total Problems. These findings converge with those found by Vitolo et al. (2005), which showed a $35.2 \%$ prevalence rate of mental health problems in a school population, indicating the need for assistance of this population, notably lacking this type of intervention.

Another important result was that Control Group had higher number of children who exposed to suicides $(22.9 \%$ vs. $1.6 \%)$, suicides attempts $(31.4 \%$ vs. $6.5 \%)$ and death $(42.9 \%$ vs. $19.4 \%)$ in the family during the previous years. Death of a family member entered the logistic regression model with significance $(p=.007)$, being the children of the Intervention Group more protected regarding this fact $(O R=$ .161). These results may demonstrate that Intervention Group had a better family structure, protecting its members from these types of occurrences. This healthier family structure may also explain the fact that children were taken to CUIDA.

It is interesting to notice that the variable "Substance Abuser Member" entered the logistic regression model with significance $(p=.019, O R=5.859)$. Although for both groups the number is very high, Intervention Group has a greater number $(86.4 \%)$ of first-degree relatives (mother, father and/ or siblings) suffering from addiction than the Control Group (71.4\%). It is possible to hypothesize that the greater proximity to the substance abuser, the greater the losses of affected children. On the other hand, our data have shown that the caregivers of these children report less emotional/behavioral problems than caregivers from Control Group, which may suggest that preventive intervention acts as a protective factor, showing that prevention services like CUIDA are likely to be effective on underprivileged communities.
It is worth mentioning, however, that although families from the Intervention Group may be considered more protected, since they have sought assistance, they were still families in need of this kind of assistance, because of all the risk factor they experience by having a substance abuser within them. This fact highlights the need for such intervention to be carried out on a large scale, especially when observing the differences in rates of mental health problems found in the sample that participated in the preventive program in comparison to who did not participate, and also in epidemiological studies with the general population conducted in our country (Feitosa et al., 2011; Paula et al., 2007; Vitolo et al., 2005).

Noteworthy among the results is the variable Religion, which showed high significance level $(p=.003)$, indicating to be a protection factor for the Intervention Group $(O R=$ .095). It can be inferred that having a religion is associated with a better outcome with regard to children's mental health, which was also observed in a study of Cucchiaro and Dalgalarrondo (2007).

Although there was no difference between the groups with regard to socioeconomic status, this should certainly be a concern, since adverse economic conditions collaborate to worse prognosis in mental health problems (Feitosa et al., 2011). The vulnerable social condition of the population studied is added to the vulnerability of being children of substance abusers, dealing with violence of which children are usually direct or indirect victims. This scenario further increases the risk of psychological and psychiatric problems (Kumpfer \& Johnson, 2007).

Both groups were composed of children who live in the same neighborhood, regulars of centers from the same institution, with similar economic status and living with users of the same type of drugs (alcohol or illicit). Thus, potential biases in the study were minimized. However, there are limitations involving the presented study that must be addressed to delimitate the reach of the results found.

Data from CBCL are not provided by the children, but rather by their mothers or guardians. Researches (Linares et al., 2006) consider essential to ponder over the effect that the informants have in the assessment, because information given by parents about children behavior problems are affected by their own psychological problems. Since we were not able to assess informant's mental health status, this is a bias to be considered, although CBCL is a world known instrument with proven sensitivity and widely used for such studies (Achenbach \& Rescorla, 2007).

Another issue is a constraint on the number of participants. Having this population high-risk of vulnerability, a great level of difficulty was found in establishing contact with the families who have been monitored by CUIDA. Many had changed their address and telephone number, making it impossible to reach them. Therefore, it was not possible to contact the entire population that received the intervention, but only $38 \%$ of those who were within inclusion criteria. And even when reached, a selection bias is noteworthy, since the participation was voluntary and $22 \%$ refused to participate. Besides, the number of participants on the 
Control Group is lower and it was not possible to pair them with the Intervention Group regarding all variables, which definitely would enhance the legitimacy of the mental health differences found on our study.

In addition, the methodology does not allow causality relation; however, it indicates the presence of an association, as well as directions for further studies within this population. Nevertheless, despite any attention given to children in Brazil, no research, up to the present moment, has presented results from a prevention intervention program with children exposed to substance abuse in their families.

Inlinewithinternational and national studies, implications can be found for the mental health of children living in a poor environment with substance abusers, domestic violence and social risk. Knowing the severity of impact of mental disorders in childhood and, as well as the high rates of these disorders especially in poorer regions, our findings highlight the need for deployment and implementation of preventive mental health centers (Curto, Paula, do Nascimento, Murray, \& Bordin, 2011; Paula, Lauridsen-Ribeiro, Wissow, Bordin, \& Evans-Lacko, 2012). According to Fleitlich and Goodman (2002), these centers should be concentrated on the areas of lower socioeconomic level, where prevalence rates of mental health problems are higher, as in the region of this study. They should also prioritize prevention and treatment of the most common disorders, offering standardized tested treatments and diagnostic assessment.

In addition to the implementation of prevention and care centers, further research should also be conducted, both to investigate the impacts of adverse problems for the development of children, and to develop strategies for prevention and health promotion aimed to mental health. Thus, apart from immediately improve the quality of life of these children, it shall be observed an impact on the future of these young people by favoring the reduction of school failure and dropout, criminality, substance abuse, development of personality or other mental disorders and the feasibility of preventive health care against the use of psychoactive substances and mental health (Fatori, EvansLacko, Bordin, \& Paula, 2012).

In conclusion, it is noteworthy that being CUIDA a one of a kind facility in Brazil, there are no other studies to compare the data with. The research here presented is one of the few conducted in the country regarding prevention on children exposed to substance abusers and it points to a positive association between preventive intervention program and protection of emotional and behavioral problems in children. These first results should collaborate with the literature findings concerning this theme. For this reason, it validates the importance of investing in services and public policies in order to promote the mental health of those children at risk, direct victims of alcohol and drugs abuse by their families.

\section{References}

Achenbach, T. M., \& Rescorla, L. A. (2001). Manual for the ASEBA school-age forms \& profiles. Burlington, VT: University of Vermont, Research Center for Children, Youth, \& Families.
Achenbach, T. M., \& Rescorla, L. A. (2007). Multicultural supplement to the manual for the ASEBA school-age forms \& profiles. Burlington, VT: University of Vermont, Research Center for Children, Youth, \& Families.

Adkison, S. E., Grohman, K., Colder, C. R., Leonard, K., Orrange-Torchia, T., Peterson, E., \& Eiden, R. D. (2013). Impact of fathers' alcohol problems on the development of effortful control in early adolescence. Journal of Studies on Alcohol and Drugs, 74(5), 674-683. doi:10.15288/ jsad.2013.74.674

Assis, S. G., Avanci, J. Q., Pesce, R. P., Oliveira, R. V. C., \& Furtado, L. X. (2007). A violência familiar produzindo reversos: Problemas de comportamento em crianças escolares (relatório de pesquisa) [Family violence producing perverse: Behavior problems in school children (research report)]. Rio de Janeiro, RJ: Claves/Fiocruz.

Barnow, S., Ulrich, I., Grabe, H. J., Freyberger, H. J., \& Spitzer, C. (2007). The influence of parental drinking behaviour and antisocial personality disorder on adolescent behavioural problems: Results of the Greifswalder family study. Alcohol and Alcoholism, 42(6), 623-628. doi:10.1093/alcalc/agm051

Beard, J., Biemba, G., Brooks, M. I., Costello, J., Ommerborn, M., Bresnahan, M., . . . Simon, J. L. (2010). Children of female sex workers and drug users: A review of vulnerability, resilience and family-centred models of care. Journal of the International AIDS Society, 13(Suppl. 2), S6. doi:10.1186/1758-2652-13-S2-S6

Bordin, I. A., Rocha, M. M., Paula, C. S., Teixeira, M. C. T. V., Achenbach, T. M., Rescorla, L. A., \& Silvares, E. F. M. (2013). Child Behavior Checklist (CBCL), Youth Self-Report (YSR) and Teacher's Report Form (TRF): An overview of the development of the original and Brazilian versions. Cadernos de Saúde Pública, 29(1), 13-28. doi:10.1590/S0102-311X2013000100004

Bordin, I. A. S., Mari, J. J., \& Caeiro, M. F. (1995). Validação da versão brasileira do Child Behavior Checklist (CBCL) - Inventário de Comportamentos da Infância e da Adolescência: Dados preliminares [Validation of the Brazilian version of the Child Behavior Checklist (CBCL): Preliminary data]. Revista ABPAPAL, 17(2), 5566.

Brasil, H. H. A., \& Bordin, I. A. (2010). Convergent validity of K-SADS-PL by comparison with CBCL in a Portuguese speaking outpatient population. BMC Psychiatry, 10, 83. doi:10.1186/1471-244X-10-83

Bröning, S., Kumpfer, K., Kruse, K., Sack, P.-M., SchaunigBusch, I., Ruths, S., . . Thomasius, R. (2012). Selective prevention programs for children from substanceaffected families: A comprehensive systematic review. Substance Abuse Treatment, Prevention and Policy, 7, 23. doi:10.1186/1747-597X-7-23

Buu, A., Wang, W., Schroder, S. A., Kalaida, N. L., Puttler, L. I., \& Zucker, R. A. (2012). Developmental emergence of alcohol use disorder symptoms and their potential as early indicators for progression to alcohol dependence in a high risk sample: A longitudinal study from childhood 
to early adulthood. Journal of Abnormal Psychology, 121(4), 897-908. doi:10.1037/a0024926

Chen, Y., Li, X., Zhang, C., Hong, Y., Zhou, Y., \& Liu, W. (2013). Alcohol use and sexual risks: Use of the Alcohol Use Disorders Identification Test (AUDIT) among female sex workers in China. Health Care for Women International, 34(2), 122-138. doi:10.1080/07399332.2 011.610535

Cucchiaro, G., \& Dalgalarrondo, P. (2007). Mental health and quality of life in pre- and early adolescents: A schoolbased study in two contrasting urban areas. Revista Brasileira de Psiquiatria, 29(3), 213-221. doi:10.1590/ S1516-44462007000300005

Curto, B. M., Paula, C. S., do Nascimento, R., Murray, J., \& Bordin, I. A. (2011). Environmental factors associated with adolescent antisocial behavior in a poor urban community in Brazil. Social Psychiatry and Psychiatric Epidemiology, 46(12), 1221-1231. doi:10.1007/ s00127-010-0291-2

Fatori, D., Bordin, I. A., Curto, B. M., \& Paula, C. S. (2013). Influence of psychosocial risk factors on the trajectory of mental health problems from childhood to adolescence: A longitudinal study. BMC Psychiatry, 13, 31. doi:10.1186/1471-244X-13-31

Fatori, D., Evans-Lacko, S., Bordin, I. A., \& Paula, C. (2012). Child mental health care in Brazil: Barriers and achievements. The Lancet, 379(9812), e16-e17. doi:10.1016/S0140-6736(12)60105-6

Feitosa, H.N., Ricou, M., Rego, S., \& Nunes, R. (2011).A saúde mental das crianças e dos adolescentes: Considerações epidemiológicas, assistenciais e bioéticas [Mental health of children and teens: Epidemiological, assistance and bioethical considerations]. Revista Bioética, 19(1), 259275. Retrieved from http://revistabioetica.cfm.org.br/ index.php/revista_bioetica/article/viewFile/521/636

Figlie, N., Fontes, A., Moraes, E., \& Payá, R. (2004). Filhos de dependentes químicos com fatores de risco bio-psicosociais: Necessitam de um olhar especial? [Children of addicted parents with bio-psychosocial risk factors: Do they need a special care?]. Revista de Psiquiatria Clínica, 31(2), 53-62. doi:10.1590/S0101-60832004000200001

Figlie, N. B., Milagres, E., \& Crowe, J. (2009). Família e dependência química: Uma experiência de prevenção com crianças e adolescentes no Jardim Ângela [Family and addiction: An experience of prevention with children and adolescents in Jardim Ângela]. São Paulo, SP: Roca.

Fleitlich, B., \& Goodman, R. (2001). Social factors associated with child mental health problems in Brazil: Cross sectional survey. British Medical Journal, 323(7313), 599-600. doi:10.1136/bmj.323.7313.599

Fleitlich, B. W., \& Goodman, R. (2002). Implantação e implementação de serviços de saúde mental comunitários para crianças e adolescentes [Deployment and implementation of community mental health facilities for children and adolescents]. Revista Brasileira de Psiquiatria, 24(1), 2. doi:10.1590/S151644462002000100002
Frank, S. H., Graham, A. V., Zyzanski, S. J., \& White, S. (1992). Use of the Family CAGE in screening for alcohol problems in primary care. Archives of Family Medicine, 1(2), 209-216.

Huculak, S., McLennan, J. D., \& Bordin, I. A. S (2011). Exposure to violence in incarcerated youth from the city of São Paulo. Revista Brasileira de Psiquiatria, 33(3), 314-320. doi:10.1590/S1516-44462011000300011

Klostermann, K., Chen, R., Kelley, M. L., Schroeder, V. M., Braitman, A. L., \& Mignone, T. (2011). Coping behavior and depressive symptoms in adult children of alcoholics. Substance Use \& Misuse, 46(9), 1162-1168. doi:10.3109/10826080903452546

Kumpfer, K. L., \& Johnson, J. L. (2007). Intervenciones de fortalecimiento familiar para la prevención del consumo de sustancias en hijos de padres adictos [Strengthening family interventions for the prevention of substances abuse in children of substance abusers parents]. Adicciones, 19(1), 13-25. Retrieved from http://www. redalyc.org/pdf/2891/289122034004.pdf

Laranjeira, R., \& Hinkly, D. (2002). Evaluation of alcohol outlet density and its relation with violence. Revista de Saúde Pública, 36(4), 455-461. doi:10.1590/S003489102002000400011

Linares, T. J., Singer, L. T., Kirchner, H. L., Short, E. J., Min, M. O., Hussey, P., \& Minnes, S. (2006). Mental health outcomes of cocaine-exposed children at 6 years of age. Journal of Pediatric Psychology, 31(1), 85-97. doi:10.1093/jpepsy/jsj020

Mackrill, T., \& Hesse, M. (2012). Suicide behavior in parents with alcohol abuse problems and suicide behavior in their offspring-adult offspring and counselor perspectives. Nordic Journal of Psychiatry, 66(5), 343-348. doi:10.310 9/08039488.2011.650196

Masur, J., \& Monteiro, M. G. (1983). Validation of the CAGE alcoholism screening test in a Brazilian psychiatric inpatient hospital setting. Brazilian Journal of Medical and Biological Research, 16(3), 215-218.

Murray, J., Anselmi, L., Gallo, E. A. G., Fleitlich-Bilyk, B., \& Bordin, I. A. (2013). Epidemiology of childhood conduct problems in Brazil: Systematic review and meta-analysis. Social Psychiatry and Psychiatric Epidemiology, 48(10), 1527-1538. doi:10.1007/s00127-013-0695-x

Paula, C. S., Duarte, C. S., \& Bordin, I. A. S. (2007). Prevalence of mental health problems in children and adolescents from the outskirts of Sao Paulo city: Treatment needs and service capacity evaluation. Revista Brasileira de Psiquiatria, 29(1), 11-17. doi:10.1590/ S1516-44462006005000012

Paula, C. S., Lauridsen-Ribeiro, E., Wissow, L., Bordin, I. A. S., \& Evans-Lacko, S. (2012). How to improve the mental health care of children and adolescents in Brazil: Actions needed in the public sector. Revista Brasileira de Psiquiatria, 34(3), 334-351. doi:10.1016/j. rbp.2012.04.001

Robertson, E. B., David, S. L., \& Rao, S. A. (2003). Applying prevention principles to drug abuse prevention 
programs. In Preventing drug abuse among children and adolescents: A research-based guide for parents, educators, and community leaders (2nd ed., pp. 18-25). Bethesda, MD: National Institute on Drug Abuse.

Rocha, M. M., Rescorla, L. A., Emerich, D. R., Silvares, E. F. M., Borsa, J. C., Araújo, L. G., . . . Assis, S. G. (2013). Behavioural/emotional problems in Brazilian children: Findings from parents' reports on the Child Behavior Checklist. Epidemiology and Psychiatric Sciences, 22(4), 329-338. doi:10.1017/S2045796012000637

Serec, M., Svab, I., Kolšek, M., Svab, V., Moesgen, D., \& Klein, M. (2012). Health-related lifestyle, physical and mental health in children of alcoholic parents. Drug and Alcohol Review, 31(7), 861-870. doi:10.1111/j.14653362.2012.00424.x

Temple, J. R., Shorey, R. C., Fite, P., Stuart, G. L., \& Le, V. D. (2013). Substance use as a longitudinal predictor of the perpetration of teen dating violence. Journal of Youth and Adolescence, 42(4), 596-606. doi:10.1007/s10964012-9877-1

Trim, R. S., \& Chassin, L. (2008). Neighborhood socioeconomic status effects on adolescent alcohol outcomes using growth models: Exploring the role of parental alcoholism. Journal of Studies on Alcohol and Drugs, 69(5), 639-648.

Vitolo, Y. L. C., Fleitlich-Bilyk, B., Goodman, R., \& Bordin, I. A. S. (2005). Crenças e atitudes educativas dos pais e problemas de saúde mental em escolares [Parental beliefs and child-rearing attitudes and mental health problems among schoolchildren]. Revista de Saúde Pública, 39(5), 716-724. doi:10.1590/S0034-89102005000500004

Thaís dos Reis Vilela is a Ph.D. candidate of the Graduate Program in Psychiatry and Medical Psychology at the Universidade Federal de São Paulo.

Rebeca de Souza e Silva is a Full Professor at the Universidade Federal de São Paulo.

Camila Garcia de Grandi is a M.S. in Psychiatry and Medical Psychology from Universidade Federal de São Paulo.

Marina Monzani da Rocha is a Professor of the Centro de Ciências Biológicas e da Saúde at the Universidade Presbiteriana Mackenzie.

Neliana Buzi Figlie is an Affiliated Professor of the Escola Paulista de Medicina at the Universidade Federal de São Paulo.

Received: June 2, 2015

1st Revision: Oct. 24, 2015

Approved: Dec. 15, 2015

How to cite this article:

Vilela, T. R., Silva, R. S., Grandi, C. G., Rocha, M. M., \& Figlie, N. B. (2016). Emotional and behavioral problems in children living with addicted family members: Prevention challenges in an underprivileged suburban community. Paidéia (Ribeirão Preto), 26(64), 225-234. doi:10.1590/1982-43272664201610 